引用格式: 高阳, 刘悦忻, 钱建利, 等. 基于多源数据综合观测的生态安全格局构建: 以江西省万年县为例 [J]. 资源科学, 2020, 42(10): 2010-2021. [Gao Y, Liu Y X, Qian J L, et al. Improving ecological security pattern based on the integrated observation of multiple source data: A case study of Wannian County, Jiangxi Province[J]. Resources Science, 2020, 42(10): 2010-2021.] DOI: 10.18402/resci.2020.10.17

\title{
基于多源数据综合观测的生态安全格局构建 以江西省万年县为例
}

\author{
高阳 ${ }^{1,2}$, 刘悦忻 ${ }^{1,2}$, 钱建利 ${ }^{3}$, 郭 游 ${ }^{4}$, 胡迎山 ${ }^{4}$
}

（1. 中国农业大学土地科学与技术学院, 北京 $100193 ; 2$. 自然资源部农用地质量与监控重点 实验室, 北京 $100193 ; 3$. 中国地质调查局西安矿产资源调查中心, 西安 710100 ; 4. 中国地质调查局

自然资源综合调查指挥中心,北京 100055)

摘要: 全面掌握区域自然资源现状, 以此为数据基础进行生态安全格局优化,对综合开发及统筹布局自然资源 具有重要意义。开展自然资源综合观测、识别区域生态保护及修复节点是安全格局构建的关键环节。本文选取江 西省万年县为研究区，通过土地利用类型、DEM、道路数据和自然保护地数据对区域资源现状进行综合观测; 同时 基于 InVEST 模型、粒度反推法以及区域现状确定生态源地; 结合土地利用类型、地形以及道路因子构建综合阻力 面; 并使用电路理论判定生态廊道, 识别生态修复关键点。结果表明: (1)万年县生态源地面积 $95.93 \mathrm{~km}^{2}$, 林地为主 要源地类型, 其对于区域生态安全格局的稳定至关重要; 生态廊道长度 $217.89 \mathrm{~km}$, 其中, 贯穿全域的 33 条关键廊道 需要优先保护, 未来可作为自然资源综合观测及监测的重点区域。(2)识别出“夹点”11处, “障碍点”74处, 区域生境 连通性仍有较大提升空间。(3)基于电路理论,通过源地选取、阻力面及廊道构建、重要战略点识别等,整合全域山 水林田湖草自然资源, 针对生态安全格局提出不同分区的资源优化策略, 对于提高区域资源供给能力具有积极的 实践意义。

关键词: 综合观测; 生态安全格局; 生态廊道; 重要战略点;资源优化分区; 指标选取;电路理论;万年县

DOI :10.18402/resci.2020.10.17

\section{1 引言}

20 世纪 90 年代以来, 随着城镇化的快速发展, 各地区经济发展与效益同步提升 ${ }^{[1]}$,但由于中国区 域内部景观异质性较强, 自然资源尤其是优质自然 资源极为有限,地区发展面临着建设空间不足、耕 地保护压力大、生态环境退化明显等挑战 ${ }^{[2,3]}$,一定 程度上限制了经济社会可持续发展 ${ }^{[4]}$, 因此迫切需 要全面掌握区域自然资源利用现状及禀赋,并以此 为基础进行生态安全格局优化。2020年,面对生态
文明建设需求,中国开始重视自然资源要素综合观 测能力,准确把握自然资源分布、变化规律,可为资 源安全状况调查和判断提供长期的数据支持, 为自 然资源管理提供科学有效的数据基础和决策依 据。以社会、经济、生态效益最优为目标,利用一定 的技术手段,统筹布局区域内自然和人为要素,维 持区域生态系统结构与功能的完整性,实现山水林

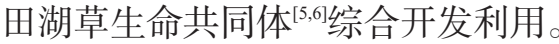

生态安全格局以景观生态学为理论支持,起源

收稿日期: 2020-05-06 修订日期: 2020-08-21

基金项目: 国家社会科学基金青年项目(19CGL037); 全国自然资源要素综合观测体系规划与部署项目(DD20208063);自然资源要素综合观 测数据集成与应用服务项目 (DD20208067)。

作者简介:高阳,女,北京人,副教授,研究方向为土地利用/覆被变化、生态系统服务。E-mail: yanggao@cau.edu.cn 通讯作者: 刘悦忻,女,山东东营人,硕士研究生,研究方向为生态安全格局。E-mail: SY20193030389@cau.edu.cn 
于景观生态规划方法, 其实质是基于自然与发展相 互作用机制和人类干扰途径, 识别生态恢复和适合 生物保护的区域空间 ${ }^{[7]}$ 。目前, 国外学者大多从生 态网络 ${ }^{[8,9]}$ 、绿色基础设施 ${ }^{[10]}$ 等角度对区域的生态状 况加以评估, 而在国内, 经过学者的一系列探索, 逐 步形成了“源地-阻力面-生态廊道”的研究范式 ${ }^{[11-13]}$, 如何科学客观地识别生态源地, 构建阻力面, 确定 生态廊道是当前研究的重点。随着“3S”技术的迅 速发展, 学者纷纷在生态安全格局构建方法中融人 了遥感数据处理及生态过程动态模拟等手段。如 通过生态系统服务重要性分析 ${ }^{[14-16]}$ 、敏感性分析 ${ }^{[17-20]}$, 生态系统服务价值计算 ${ }^{[21,22]}$, 多目标遗传算法 ${ }^{[23]} 、$ 粒 度反推 ${ }^{[24]}$ 等方法识别生态节点; 或采取应用最广泛 的最小累积阻力模型, 基于 “源-汇” 理论把物种移 动过程中克服累积阻力最小的通道识别为生态廊 道 ${ }^{[25-28]}$ 。还可通过水文分析以 DEM 为数据基础, 提 取低阻力谷线为生态廊道 ${ }^{[2,30]}$, 识别基于景观的最 小耗费路径。2006年, McRae 首次将物理学中的电 路理论知识融人到景观生态学中 ${ }^{[31]}$, 假设景观中物 种的迁移过程具有类似电子的特性, 即在电路中随 机流动, 从而识别出基础景观面中的多条移动路 径, 并可通过源地之间的电流强度确定生境节点和 廊道的相对重要性 ${ }^{[32]}$, 常被国外学者用于物种栖息 地之间的连通性分析, 且尝试将电路理论应用于识 别潜在保护区域和廊道上 ${ }^{[33,34]}$ 。电路理论整合了生 态源地间的结构性廊道, 突破了最小累积阻力模型 仅识别最小成本路径的局限。景观连通性主要影 响节点的识别, 对区域生态安全格局的保护与修复 有重要意义。目前, 国内基于电路理论构建生态安 全格局的研究较少 ${ }^{[35,36]}$ 。

万年县处于长江中下游平原, 素有 “鱼米之乡” 之称, 但近年来随着耕地面积进一步扩大, 农业活 动愈加密集, 同时伴随着矿山的开采, 建设用地的 进一步扩张, 导致生物多样性严重受损, 存在许多 潜在的生态威胁。故本文在整合自然资源观测数 据基础上, 基于 Circuitscape 4.0 平台, 结合电路理论 对生态源地斑块的景观连通性进行分析, 识别关键 及潜在生态廊道, 进行保护修复分区, 识别待保护 “夹点” 和待移除“障碍点”, 以期为县域生态保护与 修复工作提供借鉴。

\section{2 数据来源与研究方法}

\section{1 研究区概况}

万年县地处江西省上饶市中西部, 鄱阳湖之 滨。总面积 $1150.20 \mathrm{~km}^{2}$, 常住人口 43.57 万人, 境内 地势由东南向西北呈阶梯状倾斜(图 1)。属亚热带 季风性湿润气候, 作为人工栽培稻和贡米的原产 地, 其耕作土壤以水稻土为主, 广泛分布于低丘以 及西北部乐安河及其支流附近的冲积平原。境内 共有 3 条高速公路及一条铁路穿过, 分别是杭长高 速、济广高速、上万高速以及皖赣铁路。2019年,万 年县政府提出建设 “山水林田湖草一体化生态城” 的战略目标, 区域绿色发展及生态安全格局的打造 成为万年县未来的重点发展方向。

\section{2 数据来源及处理}

自然资源要素综合观测是全面掌握研究区资 源禀赋的手段,其中,调查是针对自然资源要素开 展的首要工作 ${ }^{[37]}$,根据自然资源调查对象与技术要 求 ${ }^{[38]}$, 从遥感数据源选取、数据处理及实地调研 3 个 方面展开调查：

(1)遥感数据选取: 高程数据来自地理空间数 据云平台, 空间分辨率为 $30 \mathrm{~m}$; 万年县遥感影像来 自BIGEMAP平台 (http://www.bigemap.com/)。

(2)遥感数据处理:基于 ArcGIS10.6 平台进行 数据初步处理, 计算万年县坡度及地形起伏度; 综 合遥感影像及万年县土地利用变更调查数据库确

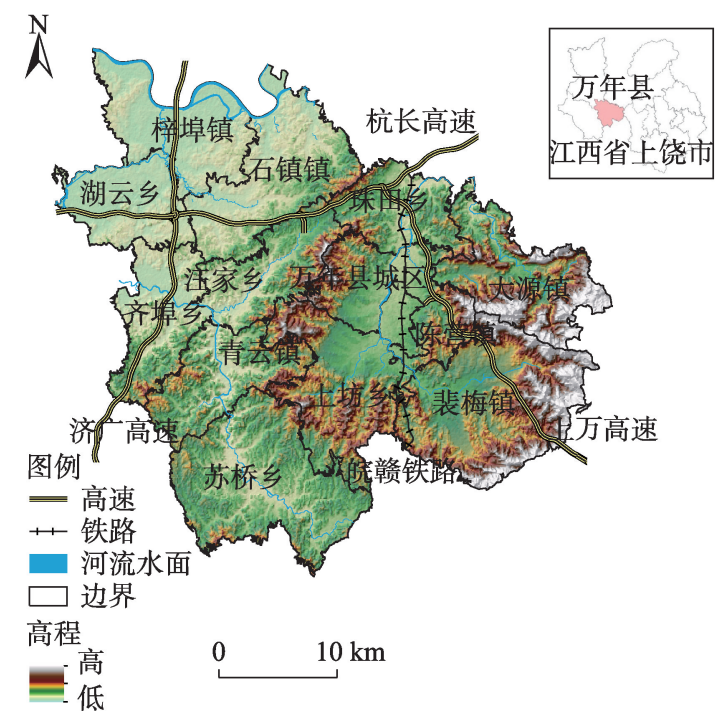

图 1 研究区概况

Figure 1 The study area 
定具体土地利用类型，包括各地类图斑名称、面积 等相关属性;将上饶市自然保护地图矢量化得到自 然保护地分布。所有数据统一处理为 $30 \mathrm{~m} \times 30 \mathrm{~m}$ 栅 格数据形式。

(3) 实地调研: 确定万年县重要村镇点, 沿其主 要道路明晰周边林草地分布及建筑物属性, 采用路 线观测及点观测对万年县土地利用/覆被进行小范 围校核。

通过上述基础调查获取万年县森林及草场、 水、耕地等资源空间分布情况，同时从 OpenStreetMap 平台获取铁路、国道等数据, 以各级道路作为 连接, 以道路交叉口为节点构建路网, 综合自然及 人文要素数据, 以此为基础进行生态安全格局 构建。

\section{3 研究方法}

\subsection{1 生态源地选取}

(1)生境质量模型 (Habitat Quality Model)

InVEST 模型中的生境质量模型基于生境受人 类活动的干扰程度计算生态系统提供生存条件的 潜力。依据模型设置, 从胁迫因子相对影响、生境 类型对胁迫因子的敏感程度、生境与胁迫因子之间 的实际距离 3 个方面考虑了胁迫因子对生境斑块的 干扰程度。通过查阅 InVEST 模型指南、相关研究 以及万年县自然条件 ${ }^{[39-42]}$, 选择生境类型为林地、草 地和水域, 胁迫因子为农村居民点、采矿用地、公 路、铁路、农村道路, 并进一步确定胁迫因子的最大 影响距离和各个土地利用类型对胁迫因子的敏感 性,计算得到万年县生境质量,计算公式如下：

$$
Q_{x j}=H_{j}\left[1-\left(\frac{D_{x j}^{z}}{D_{x j}^{z}+k^{z}}\right)\right]
$$

式中: $Q_{x j}$ 为土地利用类型为 $j$ 的栅格 $x$ 的生境质量, $H_{j}$ 表示地类 $j$ 的生境适宜性, $D_{x j}$ 表示地类 $j$ 的栅格 $x$ 的生境退化程度, $k$ 为半饱和常数,一般设置为 $0.50, z$ 为模型默认参数,一般为 2.50 。

(2)粒度反推法

粒度反推法基于数学反证法思想,对不同粒度 水平下的研究对象进行连通性分析,计算其景观格 局指数, 确定最优粒度从而反选生态源地 ${ }^{[3]}$ 。以初 步生态源地为基础, 生成 50、100、200、400、600、
$800 、 1000 、 1200 \mathrm{~m}$ 不同粒度栅格图,利用 Fragstats 软件计算各粒度水平下的斑块数 (NP)、景观分裂指 数 (DIVISION)、有效粒度面积指数 $(\mathrm{MESH}) 、$ 分离 度 (SPLIT)、斑块凝聚度 (COHESION) 以及最大斑 块指数 (LPI) 六大景观格局指数, 相隔较近的生态 斑块在粒度增加过程中不断合并, 细小斑块被剔 除,形成连通性较好的景观组分。

结合最优粒度水平,用自然断点法将生境质量 分为 5 级, 选取最高级别生境并结合万年县自然保 护地、森林公园等对其进行篮选,由于细碎斑块辐 射范围有限,故选择生境面积大于 $2 \mathrm{~km}^{2}$ 的斑块作 为生态源地。

\subsection{2 综合生态阻力面构建}

物种在区域间进行空间运动需要克服阻力,阻 力面作为构建廊道的基本要素,对生态安全格局的 构建起着重要作用。传统阻力面构建主要依据玟 块景观类型来模拟生态阻力 (显性阻力), 指标略显 单一, 为更准确客观地模拟阻力分布,借鉴相关研 究,除显性阻力面外,选取代表地貌条件的指标和 道路阻力指标共同构建综合生态阻力面, 各因子及 权重设置主要参考已有研究 ${ }^{[44-46]}$ (表 1)。

\subsection{3 廊道构建及“夹点”“障碍点”识别}

电路理论利用电子在电路中随机游走的特性 来模拟物种个体或种群在某一景观面中的迁移运 动过程 ${ }^{[47,48]}$, 其中, 电子定义为物种个体, 电导面定 义为区域景观, 电阻值依据此处景观类型是否有利 于物种扩散迁移而设定,生境质量较好的自然生态 斑块作为节点 ${ }^{[4,50]}$ 。模拟时, 由一个节点向其余节 点输人电流, 通过每个栅格的电阻值进行电路运 算, 可以计算出这两个节点之间的电流密度值, 即 电流强度,其大小可以表示物种沿节点之间某一路 径移动的概率。本文基于 Circuitscape 4.0 平台, 选 择模拟研究区生态斑块间连通性的方法为成对计 算,计算过程如下：

(1)计算综合阻力面上所有像元到源地的成本 加权距离 (Cost Weighted Distance, CWD)。

(2) 将 $C W D$ 栅格与源地叠加后计算源地间累 积移动成本路径。

(3) 由路径最小值组成最小成本距离 $L C D$, 对 
表 1 阻力因子权重与系数

Table 1 Weights and coefficients of resistance factors

\begin{tabular}{|c|c|c|c|c|}
\hline & 因子 & 权重 & 指标 & 阻力系数 \\
\hline 景观类 & & 0.40 & 湿地、林地 & 1 \\
\hline & & & 水域 & 10 \\
\hline & & & 耕地、草地 & 100 \\
\hline & & & 风景名胜区 & 200 \\
\hline & & & 园地 & 300 \\
\hline & & & 村庄用地、农村道路 & 600 \\
\hline & & & 干线公路 & 700 \\
\hline & & & 水利设施用地 & 800 \\
\hline & & & 城镇工矿建设用地 & 1000 \\
\hline & & & 其他用地 & 500 \\
\hline 地貌 & 坡度/ ${ }^{\circ}$ & 0.15 & {$[0,8]$} & 1 \\
\hline 因子 & & & $(8,15]$ & 10 \\
\hline & & & $(15,25]$ & 50 \\
\hline & & & $(25,35]$ & 75 \\
\hline & & & $(35,57]$ & 100 \\
\hline & 起伏度 $/ \mathrm{m}$ & 0.15 & {$[0,25]$} & 1 \\
\hline & & & $(25,50]$ & 10 \\
\hline & & & $(50,75]$ & 50 \\
\hline & & & $(75,100]$ & 75 \\
\hline & & & $(100,347]$ & 100 \\
\hline 道路 & 距离一级 & 0.15 & {$[0,200]$} & 100 \\
\hline 因子 & 道 路 距 & & $(200,400]$ & 80 \\
\hline & 离/m ( 铁 & & $(400,800]$ & 60 \\
\hline & 份道) & & $(800,1600]$ & 40 \\
\hline & & & $(1600,3200]$ & 20 \\
\hline & & & $(3200,19000]$ & 1 \\
\hline & 距离二级 & 0.15 & {$[0,150]$} & 100 \\
\hline & 道 路 距 & & $(150,250]$ & 80 \\
\hline & 离 $/ \mathrm{m}$ (县 & & $(250,450]$ & 60 \\
\hline & 乡道) & & $(450,800]$ & 40 \\
\hline & & & $(800,1000]$ & 20 \\
\hline & & & $(1000,2740]$ & 1 \\
\hline
\end{tabular}

应路径为最小成本路径, 即廊道。其中, 根据模型 默认参数设置将廊道分为关键及潜在廊道, 潜在廊 道可作为关键廊道的后备资源进行保护。

在此基础上,基于 Pinchpoint Mapper工具依次 连接不同生态节点 (源地), 向其他节点输人电流进 行迭代计算, 所有电流 (物种) 必须通过的节点即为 “夹点”, 是表征物种运动密度最大的区域, 需要重 点保护; 同时基于 Barrier Mapper工具, 设定 $30 \mathrm{~m}$ 的 搜索半径, 采用移动窗口法 (直径为 $D$ ) 搜索 “障碍 点”, 通过改善系数来表征(单位距离连通性恢复值 的大小), 改善系数越大, 则去除此区域后, 景观连 通性提升值越大, 识别生境内对连通性影响最大的
区域,公式如下：

$$
\begin{aligned}
\Delta L C D & =L C D_{0}-L C D_{1} \\
I S & =\Delta L C D / D
\end{aligned}
$$

式中: $\triangle L C D$ 为最小成本距离差值, $L C D_{0}$ 为最小成 本距离, $L C D_{1}$ 为障碍点移除后最小成本距离值, $I S$ 为改善系数,研究取改善系数高值前 $10 \%$ 为主要障 碍区域,通过ArcGIS工具统计其面积。

\subsection{4 生态保护修复分区}

根据区域综合保护需求划分为 3 个类型区,生 境质量最高级为生态保育区, 基于 Circuitscape 4.0 平台下的 Barrier Mapper工具进行障碍分析确定改 善区范围,并以改善系数为依据通过自然断点法将 其分为两级,改善系数较高的为一级改善区 $(0.15<$ $I S \leqslant 0.54)$, 是生态恢复的重点区域, 改善系数较低 的为二级改善区 $(0.00<I S \leqslant 0.15)$, 其余地区为发 展区。

\section{3 结果与分析}

\section{1 生态源地诊断与识别}

根据土地利用类型得到粒度为 $30 \mathrm{~m}$ 的高精度 栅格图,利用Fragstats 计算的不同粒度水平下景观 格局指数(图 2 ), 斑块数及景观分裂指数随粒度的 增加而减少, $400 \mathrm{~m}$ 之后组成数量趋于稳定; 而对于 斑块凝聚度来说, 开始随着粒度的增大略有减少, 大于 $400 \mathrm{~m}$ 之后凝聚度急剧下降, 表明存在较强连 通性的景观粒度水平为 $400 \mathrm{~m}$, 此粒度同样适用于 其他各指数。 $400 \mathrm{~m}$ 作为各景观指数发生突变的关 键点, 可作为生态源地粒度选择的合适参照。

万年县生境质量如图 3a 所示, 平均值为 0.67 , 0.60 以上的面积占 $50.15 \%$, 整体生境质量较高。高 值区域集中在研究区东南部以及中部,面积较大且 连接成片, 主要位于裴梅镇、青云镇、大源镇、苏桥 乡及上坊乡, 土地利用类型主要为林地且地势较 高。低值区集中在中部以及西北部城镇用地, 面积 较小, 主要位于石镇镇、陈营镇以及万年县城区, 占 总面积的 $8.89 \%$ 。

研究共确定 16 块源地 (图 3b), 包括神农源省级 森林公园、乐安河、铁树岭、跑马山等,面积为 95.93 $\mathrm{km}^{2}$, 占总面积的 $8.34 \%$, 包括林地、草地和水域, 其 中林地为主要生态源地类型, 占源地总面积的 

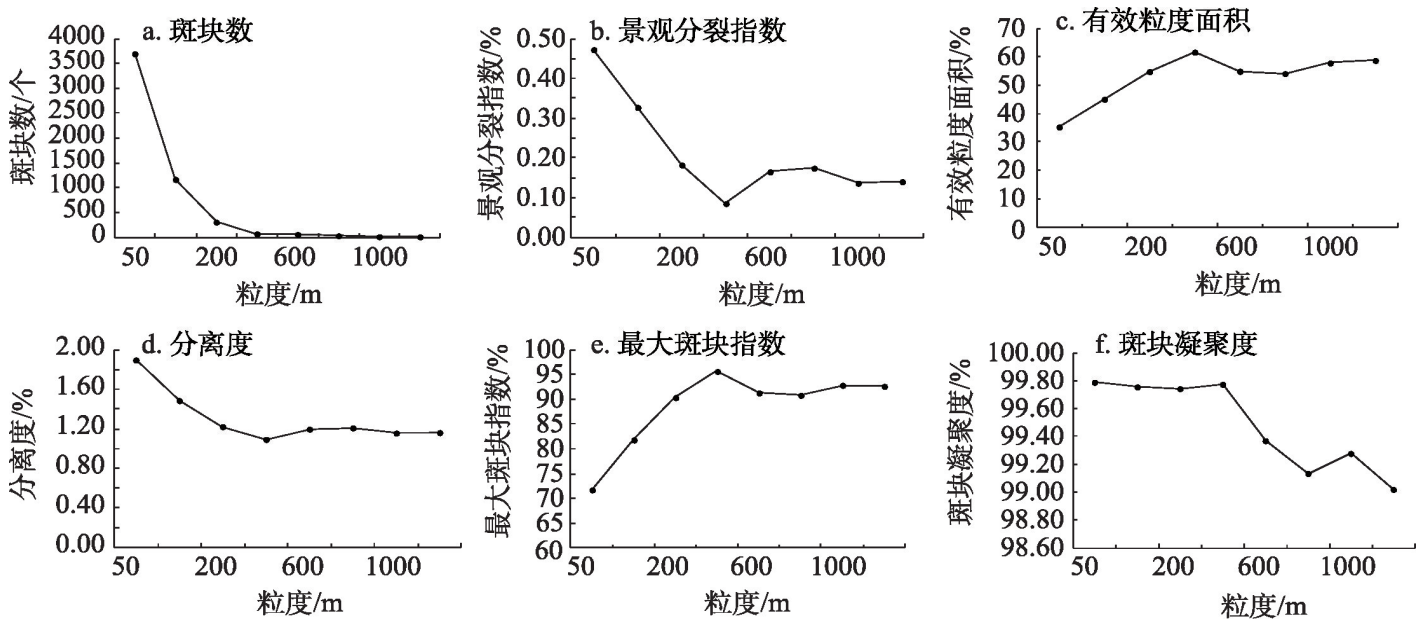

图 2 不同粒度生态景观连通性指数

Figure 2 Connectivity index of ecological landscape with different granularity (a. Number of patches; b. Landscape division index; c. Effective mesh size metric; d. Splitting index; e. Largest patch index; f. Patch cohesion index)
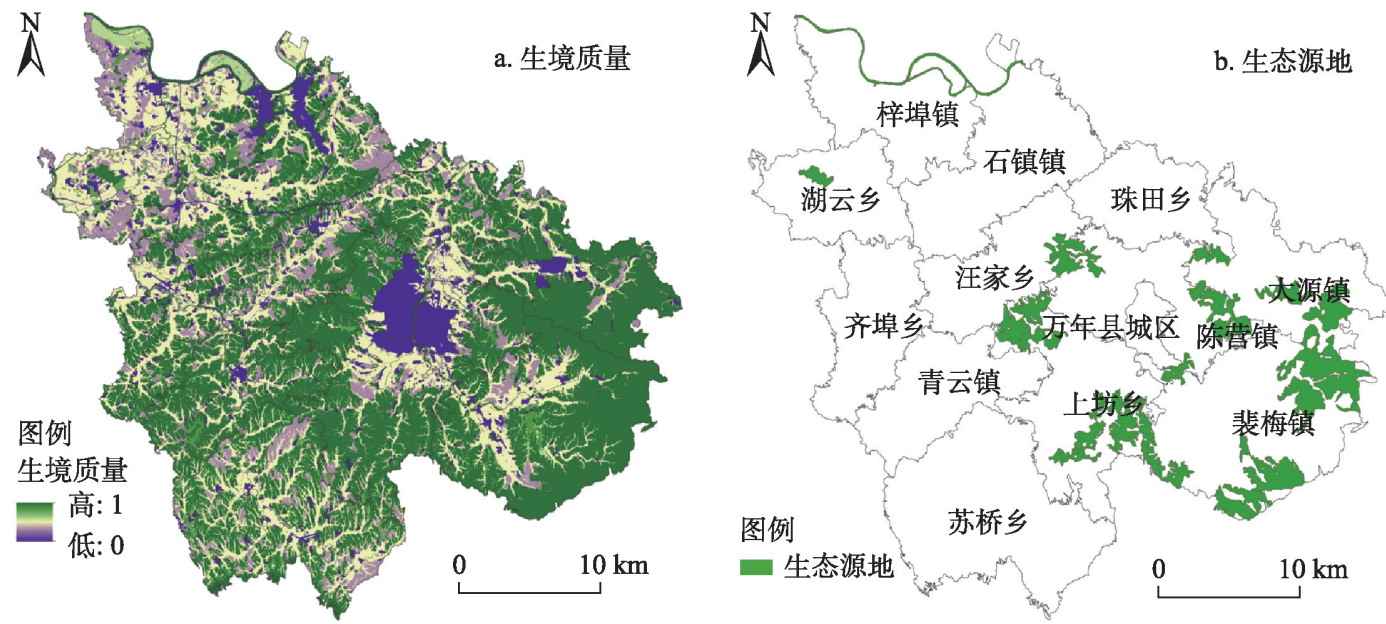

图 3 万年县生境质量 $(\mathbf{a})$ 及最终生态源地 $(\mathbf{b})$

Figure 3 Habitat quality of Wannian County (a) and the final ecological sources (b)

$93.11 \%$ 。裴梅镇生态源地面积最大, 达 $38.36 \mathrm{~km}^{2}$ 。

\section{2 综合阻力面构建}

基于表 1 构建综合阻力面(图 4), 综合阻力值较 大的区域基本位于人工活动较为密集的城区以及 道路周边, 农田虽然有长势较好的植被, 但由于人 类在其周围进行农业活动及人工控制的影响, 其阻 力值也由此变高, 阻力最高值为 441.40 , 最低值为 1.00 , 平均值为 65.24 。阻力值分布整体来说比较细 碎, 与土地利用类型基础阻力面相似, 在叠加各因 子阻力数据之后在地类内部阻力值会有不同的变 化,除高值区域集中位于中部城区以及西北部外, 其余均零散分布。

\section{3 关键生态廊道识别与生态安全格局构建}

生态廊道通过连接不同源地,增加区域景观连 通性, 最大化获取生态效益, 是维护区域生态安全 的基本架构 ${ }^{[4]}$ 。共识别生态廊道 44 条, 其中, 关键 廊道 33 条, 潜在廊道 11 条, 部分关键廊道和潜在廊 道在特定区段重合(图 5), 总计 $217.89 \mathrm{~km}$ 。东南部 及中部生态源地之间主要由长度在 $10 \mathrm{~km}$ 以内的短 廊道连接, 占关键廊道总数的 $78.79 \%$, 且此区域廊 道交叉重合, 是物种运动频繁的表现; 西北与东南 部生态源地相隔较远, 其主要连接廊道多在 20 30 $\mathrm{km}$ 。整体呈现 “三横两纵”的空间特征,由西北向东 南逐渐复杂化、网格化,连通性逐渐增强,形成由源 

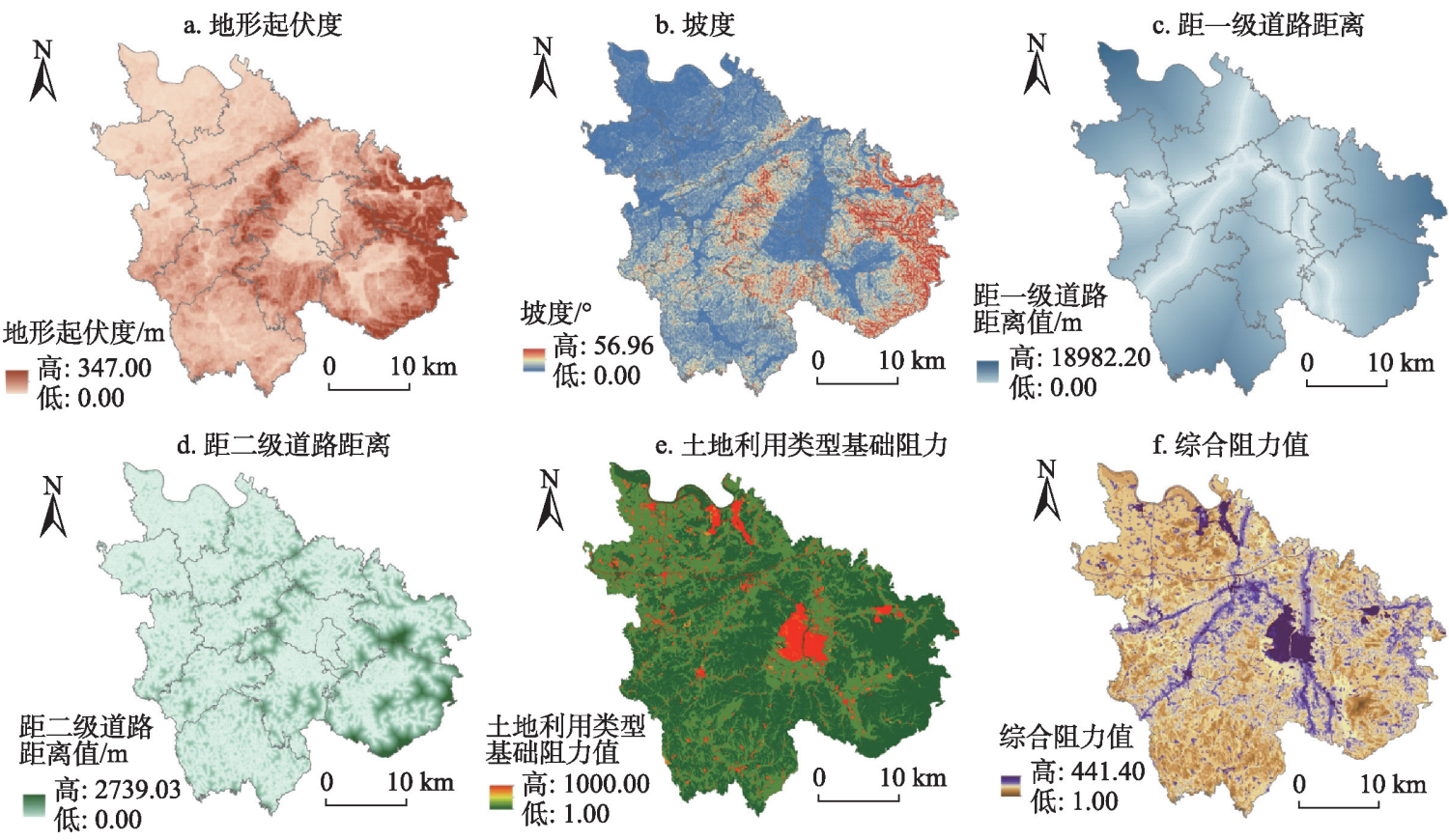

图 4 综合阻力面构建因子及结果

Figure 4 Construction factors and results of comprehensive resistance surface (a. Degree of relief; b. Slope; c. Distance from first-class roads; d. Distance from second-class roads; e. Basic resistance of land use types; f. Comprehensive resistance)

地和廊道构成的生态安全格局。

\section{4 生态保护及修复分区与关键点识别}

以自然资源观测调查数据为基础,构建万年县 生态安全格局,并根据区域综合保护需求划分为 3 个类型区(图6)。

生态保育区面积为 $394.75 \mathrm{~km}^{2}$, 占总面积的 $34.32 \%$, 主要由大面积高级别生境组成, 用地类型

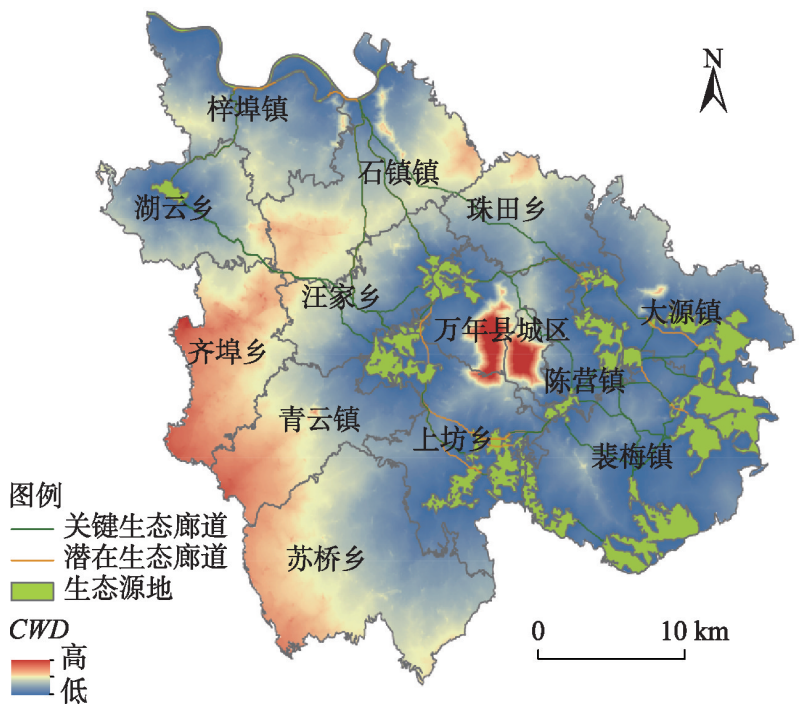

图 5 万年县生态安全格局

Figure 5 Ecological security pattern of Wannian County
主要为林地、草地和水域,少量为园地。该区植被 覆盖度高, 生物多样性丰富, 是对生物物种及其栖 息地的保存与维护,也可以通过自身强大的调节功 能对濒危优先发展。

生态改善区面积为 $258.68 \mathrm{~km}^{2}$, 占总面积的 $22.49 \%$, 主要由“障碍点” “夹点”及生态廊道组成。 物种运动密度 (电流强度) 由浅黄色到深棕色逐渐

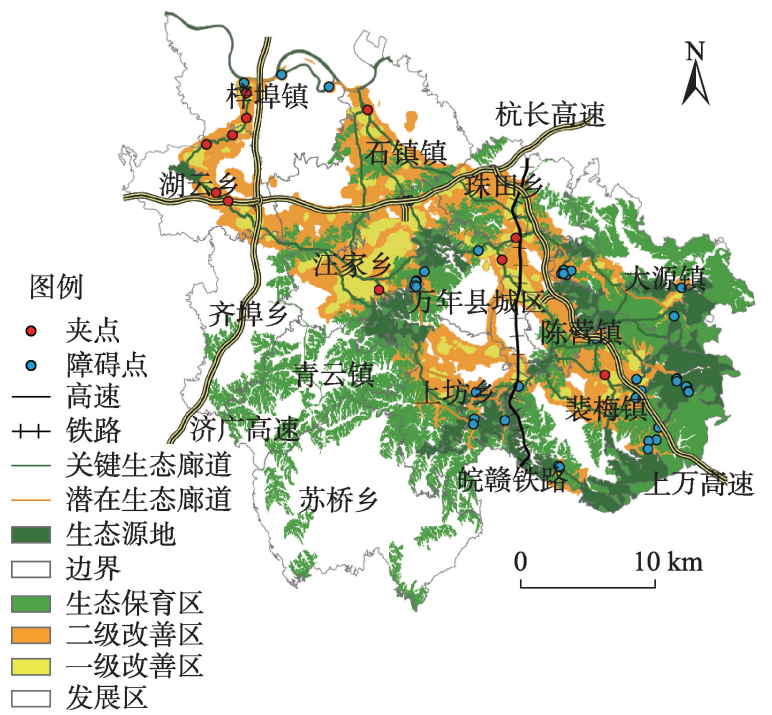

图 6 万年县保护与修复分区

Figure 6 Protection and restoration zonation of Wannian County 
增强 (图 7)。共识别“夹点”11处, 大部分都在一级 改善区内, 表明保护“夹点”区域能够显著提高景观 连通性, 其土地利用类型主要为林地和水域, 其中, 有 6 处为河流夹点, 具体包括梓埠镇 2 处, 湖云乡 2
处,珠田乡 2 处, 7 处为林地夹点, 包括湖云乡 2 处, 石镇镇 1 处, 汪家乡 2 处(表 2)。

研究共识别“障碍点”74处(图 8), 用地类型主 要为建筑用地、道路及农村居民点(表 2)。由于此

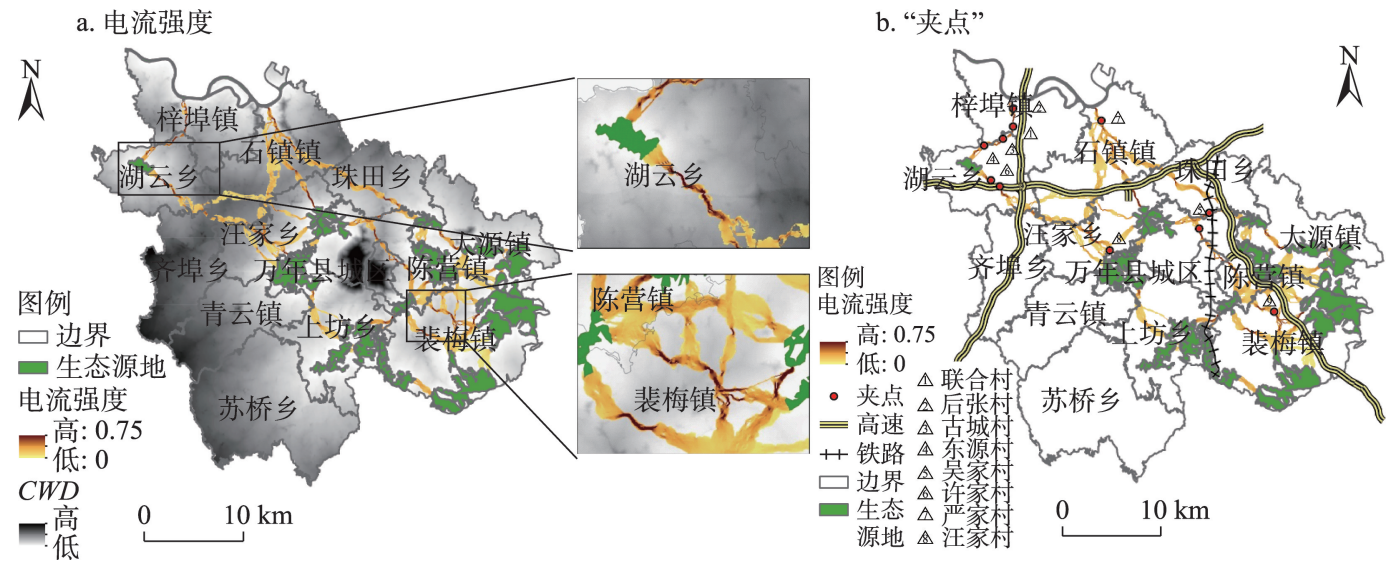

图 7 电流强度 $(\mathbf{a})$ 及“夹点”识别 $(\mathbf{b})$

Figure 7 Current intensity (a) and recognition of "pinch points"(b)

表 2 万年县保护及修复重点区域

Table 2 Key areas for protection and restoration of Wannian County

\begin{tabular}{|c|c|c|c|c|}
\hline & 现状类型 & 镇域 & 具体分布 & 存在问题 \\
\hline \multirow{11}{*}{$\begin{array}{l}\text { 待保护“夹点” } \\
\text { 区域 }\end{array}$} & \multirow[t]{6}{*}{ 河流 } & \multirow[t]{2}{*}{ 梓埠镇 } & 白竹村西侧河段 & \multirow{6}{*}{$\begin{array}{l}\text { 受到水利工程胁迫、人类农业活动等影 } \\
\text { 响, 河流逐渐萎缩、狭窄, 且存在污染 } \\
\text { 的问题 }\end{array}$} \\
\hline & & & 河东村 “石镇-桐山”国道路段旁河段 & \\
\hline & & \multirow[t]{2}{*}{ 湖云乡 } & 刘夏村北侧湖云河河段 & \\
\hline & & & 湖云河邱夏村河段 & \\
\hline & & \multirow[t]{2}{*}{ 珠田乡 } & 珠田村东侧安殷水河段 & \\
\hline & & & 珠田村南侧港前路旁河段 & \\
\hline & \multirow[t]{5}{*}{ 林地 } & \multirow[t]{2}{*}{ 湖云乡 } & 吾峰村水田旁林地 & \multirow{5}{*}{$\begin{array}{l}\text { 森林资源不断减少, 且破碎度逐渐增加, } \\
\text { 给生态环境造成压力, 使得生境之间连 } \\
\text { 通性降低 }\end{array}$} \\
\hline & & & 杭长高速吾峰村路段旁: 狮子岭林场 & \\
\hline & & 石镇镇 & $\begin{array}{l}\text { 石镇村蔬港公路与 “石镇-陈营” 国道 } \\
\text { 交叉口周边林地 }\end{array}$ & \\
\hline & & 汪家乡 & 李夏村居民点周边林地 & \\
\hline & & 裴梅镇 & 上万高速旁雅岗村路段林地 & \\
\hline \multirow{11}{*}{$\begin{array}{l}\text { 待修复“障碍点” } \\
\text { 区域 }\end{array}$} & \multirow[t]{4}{*}{ 建设用地 } & \multirow[t]{3}{*}{ 梓埠镇 } & 联合村水工堤坝(溢流坝) & \multirow{4}{*}{$\begin{array}{l}\text { 改变水体原有的流动方向和流动速度, } \\
\text { 在一定程度上阻碍了水生生物和陆生生 } \\
\text { 物的迁徙途径 }\end{array}$} \\
\hline & & & 后张村水工堤坝 (土石坝) & \\
\hline & & & 古城村水工堤坝(土石坝) & \\
\hline & & 裴梅镇 & 东源村杨家坞水库 & \\
\hline & \multirow[t]{4}{*}{ 道路用地 } & 汪家乡 & 主要分布在杭长高速两侧 & \multirow{4}{*}{$\begin{array}{l}\text { 在开发过程中对区域内植被产生不利影 } \\
\text { 响,且在公路两旁形成林间空地,造成生 } \\
\text { 境隔离 }\end{array}$} \\
\hline & & 上坊乡 & 皖赣铁路 & \\
\hline & & 裴梅镇 & 主要分布在上万高速两侧 & \\
\hline & & 陈营镇 & “宁德-福贡”国道 & \\
\hline & \multirow{3}{*}{$\begin{array}{l}\text { 农村居民点 } \\
\text { 及水田 }\end{array}$} & 陈营镇 & 吴家村、许家村居民点 (深人山区) & \multirow{3}{*}{$\begin{array}{l}\text { 人类活动密集, 现代农业技术的使用使 } \\
\text { 稻作逐渐由混种变为单种种植, 且目前 } \\
\text { 万年县种植机插率已达到 } 30 \% \text {, 部分机 } \\
\text { 械化种植地区可能会破坏生境连通性 }\end{array}$} \\
\hline & & 大源镇 & 严家村水田 & \\
\hline & & 裴梅镇 & 东源村、汪家村居民点(深人山区) & \\
\hline
\end{tabular}



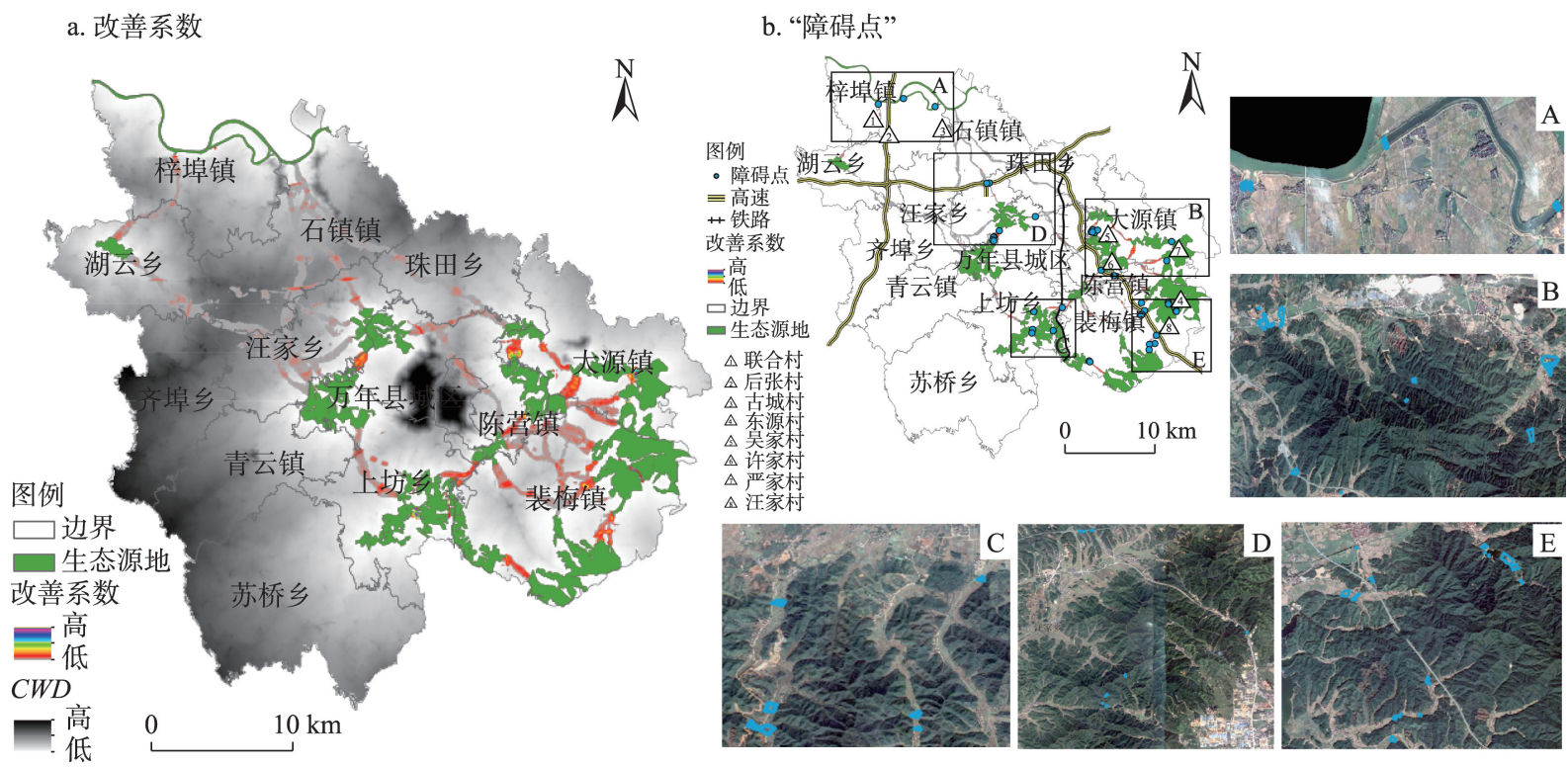

图 8 改善系数 (a)及“障碍点”识别 (b)

Figure 8 Improvement scores (a) and recognition of "barrier points" (b)

类区域人类活动往往较为密集, 空间分布上, 多数 位于生态源地和生态廊道连接处, 是连通的关键位 置, 在梓埠镇、裴梅镇、汪家乡、上坊乡、陈营镇均有 分布。障碍点所占面积越小, 代表清除此障碍点难 度越小,万年县县域内部面积小于 $1 \mathrm{hm}^{2}$ 的障碍点 个数最多, 占障碍点总数量的 $82.43 \%$, 因此万年县 区域景观连通性整体仍有较大提升空间。

\section{4 结论、建议与展望}

\section{1 结论}

自然资源是经济和社会发展重要的物质基础, 综合观测自然资源,全面掌握地区自然资源禀赋已 成为区域可持续发展和生态安全保障的关键, 以江 西省万年县为研究区, 以遥感技术为手段, 结合实 地调研, 通过土地利用类型数据、DEM数据、道路数 据对区域地形资源、水系水资源、路网与交通设施 资源以及建设用地利用现状进行综合观测。以此 为数据基础融合电路理论构建万年县生态安全格 局, 划分保护及修复分区, 识别重要保护及修复区 域,得到如下结论:

（1）基于自然资源综合观测数据构建的万年县 生态安全格局, 共识别 16 块生态源地, 面积为 95.93 $\mathrm{km}^{2}$, 主要由具有重要生态功能、生物多样性较为丰 富的林地和水域组成; 44 条生态廊道共计 217.89 $\mathrm{km}$ 。在空间分布上, 县域东南部生态源地及廊道较
为密集,生境质量较好。

(2) 万年县早期城市发展较为缓慢,近年来随 着农业活动密集度提升, 耕地面积扩大, 建设用地 扩张, 一定程度上对万年县生物多样性构成了威 胁。本文识别待保护 “夹点” 11处, 应强化生态服务 能力, 恢复生态本底质量; 识别待修复“障碍点”74 处, 分类提出修复措施, 万年县整体生境连通性仍 有较大提升空间。与此同时,政府将战略目标设定 在建设“生态城”上,今后一段时间, 需要通过 “夹 点” 的保护和“障碍点”的修复, 把握和平衡好山水 林田湖草各类自然资源, 优化资源结构。

(3) 将研究区划分为生态保育区、改善区和发 展区。其中, 生境质量指数高的为生态保育区, 主 要包括生态源地及其他生态用地, 此区域内应减少 开发建设活动; 改善区主要由“夹点”“障碍点”以及 生态廊道构成, 此区域内重点应放在对重要战略点 的保护及修复; 而发展区是城市发展和人类活动必 需的区域。未来需要对重要战略点及重要廊道进 行自然资源综合观测及监测, 依据研究区自然资源 分布现状，因地制宜打造适合其绿色发展的生态 格局。

\section{2 建议}

河流“夹点”位于水陆交界处, 不仅可以保护生 物多样性, 还具有保护水资源等其他自然资源及维 
护系统完整性等多种重要修复、调节功能, 具有极 强的不可替代性,近年来受到水利工程胁迫、人类 农业活动等影响, 河流逐渐萎缩、狭窄, 且存在一定 程度的污染问题; 同时, 林地 “夹点”受到道路等的 分割作用, 破碎度增加, 连通性降低, 保护需求日益 增加。

\subsection{1 “夹点”地区保护措施}

针对不同夹点类型, 本文提出以下保护措施：

(1)对于河流 “夹点”, 首先应当恢复河流缓冲 带, 沿岸线种植生态防护林, 使人类活动与河道保 持一定距离, 同时注意河流污染控制, 及时清淤, 提 升河流水质; 其次, 任何修复都不能局限于河道, 而 应当基于流域尺度进行生态保护, 可建立珠溪流域 及小流域资源监测工作站, 对河流内部水质以及动 植物群落的发展趋势等状况进行评估、分析以及合 理引导,以达到河流“近自然化”的目的。

(2)对于林地 “夹点”, 首先, 建议封山育林, 开 展退耕还林、还草工作, 杜绝采伐; 其次, 可依据万 年县现状选择适合的混交树种进行混交林的营造, 能够较好地改善土壤的理化性质, 维持和保护森林 系统生物多样性。

\subsection{2 “障碍点”地区保护措施}

对于 “障碍点”来说, 用地类型为非生态用地, 由此看来, 人类活动密集区域由于改变了土地下垫 面的性质对物种迁徙造成了一定程度的阻碍作用, 但因为部分交通要道以及具有重要生活功能地区 不可直接拆除,故可分类提出针对性修复措施：

(1)针对水工堤坝区域, 部分土石坝可拆除, 溢 流坝和水库保留用于分流防洪, 并在沿岸增加植被 防护。

(2)针对在重要道路两旁的障碍区域, 首先, 建 议在两旁修建隔光隔音设施, 避免某些光和噪音对 生物的生活习性造成干扰; 其次, 修建生物通道, 设 立警示牌, 保证动物移动畅通; 最后做好穿山高速 路两旁的景观设计, 减少边坡防护工作对植被的损 害, 在中央隔离带也应采取植物绿化为主的分隔方 式,保持景观多样性。

(3)针对农村居民点及水田, 首先, 可考虑推进 村庄共建, 提高土地集约利用; 其次, 通过丰富种植 品种, 如用绿肥作物与水稻套种, 避免因单一种植
造成生物多样性减少; 与此同时,在保证产量适量 的条件下减少化肥农药的使用量,使土壤性质保持 稳定。

\section{3 展望}

在未来研究中,可充实自然资源综合观测指 标, 同时进行万年县水源涵养、水土保持等生态系 统服务重要性评价, 与本文结果叠加使得生态源地 选取更为全面;在廊道构建过程中,可进一步探究 廊道适宜宽度问题。本文在障碍点识别过程中,考 虑到障碍点清除成本较高,故而选取最小的搜索半 径, 即一个像元大小 $(30 \mathrm{~m})$, 在今后研究过程中可 以设定不同的搜索半径来探究阈值设定对景观连 通障碍物判别的影响程度。

\section{参考文献(References):}

[1] 姚士谋, 张平宇, 余成, 等. 中国新型城镇化理论与实践问题[J]. 地理科学, 2014, 34(6): 641-647. [Yao S M, Zhang P Y, Yu C, et al. The theory and practice of new urbanization in China[J]. Scientia Geographica Sinica, 2014, 34(6): 641-647.]

[2] 彭建, 赵会娟, 刘炎序, 等. 区域生态安全格局构建研究进展与 展望[J]. 地理研究, 2017, 36(3): 407-419. [Peng J, Zhao H J, Liu Y X, et al. Research progress and prospect on regional ecological security pattern construction[J]. Geographical Research, 2017, 36 (3): 407-419.]

[ 3 ] 马丽, 田华征, 康蕾. 黄河流域矿产资源开发的生态环境影响与 空间管控路径[J]. 资源科学, 2020, 42(1): 137-149. [Ma L, Tian H Z, Kang L. Eco-environmental impact and spatial control of mineral resources exploitation in the Yellow River Basin[J]. Resources Science, 2020, 42(1): 137-149.]

[4] 肖铁桥, 顾康康, 杨倩倩, 等. 基于空间效能的城市生态网络构 建: 以毫州市为例[J]. 中国农业资源与区划, 2019, 40(11): 8085. [Xiao T Q, Gu K K, Yang Q Q, et al. Construction of urban ecological networks based on spatial efficiency: Bozhou City as an example[J]. Chinese Journal of Agricultural Resources and Regional Planning, 2019, 40(11): 80-85.]

[ 5 ] 匡文慧. 新时代国土空间格局变化和美丽愿景规划实施的若干 问题探讨[J]. 资源科学, 2019, 41(1): 23-32. [Kuang W H. Issues regarding on spatial pattern change of national land space and its overall implementation on beautiful vision in new era[J]. Resources Science, 2019, 41(1): 23-32.]

[6] 周宏春, 江晓军. 习近平生态文明思想的主要来源、组成部分与 实践指引[J]. 中国人口·资源与环境, 2019, 29(1): 1-10. [Zhou H C, Jiang X J. Ideological sources, components and practical guidelines of Xi Jinping Thought on Eco- civilization[J]. China 
Population, Resources and Environment, 2019, 29(1): 1-10.]

[7] 陈影, 哈凯, 贺文龙, 等. 冀西北间山盆地区景观格局变化及优 化研究: 以河北省怀来县为例[J]. 自然资源学报, 2016, 31(4): 556-569. [Chen Y, Ha K, He W L, et al. Study on the change and optimization of landscape pattern in the basin of Northwest Hebei mountains: A case study of Huailai County, Hebei Province[J]. Journal of Natural Resources, 2016, 31(4): 556-569]

[ 8 ] John F, Meir G, John L. Greenway planning: Developing a landscape ecological network approach[J]. Landscape \& Urban Planning, 1995, 33(1): 179-193.

[9] Fath B D, Scharler U M, Ulanowicz R E, et al. Ecological network analysis: Network construction[J]. Ecological Modelling, 2007.

[10] Mark B, Edward T M M. Green infrastructure: Smart conservation for the 21st Century[J]. Renewable Resources Journal, 2002, 20 (3): 13-17.

[11] Forman R T T. Land mosaics: The ecology of landscapes and regions[J]. Cambridge: Cambridge University Press, 1995.

[12] 朱军, 李益敏, 余艳红. 基于 GIS 的高原湖泊流域生态安全格局 构建及优化研究: 以星云湖流域为例 [J]. 长江流域资源与环 境, 2017, 26(8): 1237-1250. [Zhu J, Li Y M, Yu Y H. Study of construction and optimization of ecological security pattern of lake basin in plateau based on GIS: A case study of Xingyun Lake Ba$\sin [\mathrm{J}]$. Resources and Environment in the Yangtze Basin, 2017, 26 (8): 1237-1250.]

[13] 胡海龙, 马昕炜, 曾永年, 等. 多智能体与蚁群算法结合选址模 型: 长沙市生态用地选址[J]. 资源科学, 2011, 33(6): 12111217. [Hu H L, Ma X W, Zeng Y N, et al. Integration of a Site Selection Model with the Multi-Agent System and the Ant Colony Algorithm and Its Application to Changsha[J]. Resouces Science, 2011,33(6): 1211-1217.]

[14] Li Z T, Li M, Xia B C. Spatio-temporal dynamics of ecological security pattern of the Pearl River Delta urban agglomeration based on LUCC simulation[J]. Ecological Indicators, 2020, 114: 106319.

[15] Fu Y J, Shi X Y, He J, et al. Identification and optimization strategy of county ecological security pattern: A case study in the Loess Plateau, China[J]. Ecological Indicators, 2020, 112: 106030.

[16] Wang C X, Yu C Y, Chen T Q, et al. Can the establishment of ecological security patterns improve ecological protection? An example of Nanchang, China[J]. Science of the Total Environment, 2020, 740: 140051 .

[17] 杜悦悦, 胡熠娜, 杨旸, 等. 基于生态重要性和敏感性的西南山 地生态安全格局构建: 以云南省大理白族自治州为例[J]. 生态 学报, 2017, 37(24): 8241-8253. [Du Y Y, Hu Y N, Yang Y, et al. Building ecological security patterns in southwestern mountainous areas based on ecological importance and ecological sensitivity: A case study of Dali Bai Autonomous Prefecture, Yunnan Province [J]. Acta Ecologica Sinica, 2017, 37(24): 8241-8253.]
[18] 周锐, 王新军, 苏海龙, 等. 平顶山新区生态用地的识别与安全 格局构建[J]. 生态学报, 2015, 35(6): 2003-2012. [Zhou R, Wang X J, Su H L, et al. Identification and security pattern of ecological land in Pingdingshan Newly Developed Area[J]. Acta Ecologica Sinica, 2015, 35(6): 2003-2012.]

[19] 彭建, 郭小楠, 胡熠娜, 等. 基于地质灾害敏感性的山地生态安 全格局构建: 以云南省玉溪市为例[J]. 应用生态学报, 2017, 28 (2): 627-635. [Peng J, Guo X N, Hu Y N, et al. Constructing ecological security pattern in mountain areas based on geological disaster sensitivity: A case study in Yuxi City, Yunnan Province, China[J]. Chinese Journal of Applied Ecology, 2017, 28(2): 627-635.]

[20] 杨天荣, 匡文慧, 刘卫东, 等. 基于生态安全格局的关中城市群 生态空间结构优化布局[J]. 地理研究, 2017, 36(3): 441-452. [Yang T R, Kuang W H, Liu W D, et al. Optimizing the layout of eco-spatial structure in Guanzhong urban agglomeration based on the ecological security pattern[J]. Geographical Research, 2017, 36 (3): 441-452.]

[21] Wang Y, Pan J H. Building ecological security patterns based on ecosystem services value reconstruction in an arid inland basin: A case study in Ganzhou District, NW China[J]. Journal of Cleaner Production, 2019, 241: 118337.

[22] Fu Y J, Shi X Y, He J, et al. Identification and optimization strategy of county ecological security pattern: A case study in the Loess Plateau, China[J]. Ecological Indicators, 2020, 112: 106030.

[23] 张晓琳, 金晓斌, 赵庆利, 等. 基于多目标遗传算法的层级生态 节点识别与优化: 以常州市金坛区为例[J]. 自然资源学报, 2020, 35(1): 174-189. [Zhang X L, Jin X B, Zhao Q L, et al. Identification and optimization of hierarchical ecological nodes based on multi-target genetic algorithm: Take Jintan District of Changzhou as an example[J]. Journal of Natural Resources, 2020, 35(1): 174-189.]

[24] 曾黎, 杨庆媛, 杨人豪, 等. 三峡库区生态屏障区景观格局优化: 以重庆市江津区为例[J]. 生态学杂志, 2017, 36(5): 1364-1373.

[Zeng L, Yang Q Y, Yang R H, et al. Landscape pattern optimization for ecological barrier in the Three Gorges Reservoir Area: A case study in Jiangjin, Chongqing[J]. Chinese Journal of Ecology, 2017, 36(5): 1364-1373.]

[25] Klar N, Herrmann M, Henning-Hahn M, et al. Between ecological theory and planning practice: (Re-) Connecting forest patches for the wildcat in Lower Saxony, Germany[J]. Landscape and Urban Planning, 2012, 105(4): 376-384.

[26] Su Y X, Chen X Z, Liao J S, et al. Modeling the optimal ecological security pattern for guiding the urban constructed land expansions [J]. Urban Forestry \& Urban Greening, 2016, 19: 35-46.

[27] Zhang L Q, Peng J, Liu Y X, et al. Coupling ecosystem services supply and human ecological demand to identify landscape ecological security pattern: A case study in Beijing-Tianjin-Hebei region, China[J]. Urban Ecosystems, 2017, 20(3): 701-714.

[28] 王琦, 付梦娣, 魏来, 等. 基于源-汇理论和最小累积阻力模型 
的城市生态安全格局构建: 以安徽省宁国市为例[J]. 环境科学 学报, 2016, 36(12): 4546-4554. [Wang Q, Fu M D, Wei L, et al. Urban ecological security pattern based on source-sink landscape theory and MCR model: A case study of Ningguo City, Anhui Province[J]. Acta Scientiae Circumstantiae, 2016, 36(12): 4546-4554.]

[29] 刘媛. 基于 MCR 模型的志丹县土地利用生态安全格局构建 [D]. 西安: 长安大学, 2017. [Liu Y. The Construction of Land Use Ecological Security Pattern in Zhidan County Based on MCR Model[D]. Xi' an: Chang' an University, 2017.]

[30] 李渘丽. 基于 MCR 模型的县域生态用地识别及安全格局构建 [D]. 重庆: 西南大学, 2017. [Li Y L. Identification of Ecological Land and Construction of Safety Pattern in County-level Based on MCR Model[D]. Chongqing: Southwest University, 2017.]

[31] McRae B H. Isolation by resistance[J]. Evolution, 2006, 60(8): 1551-1561.

[32] McRae B H, Beier P. Circuit theory predicts gene flow in plant and animal populations[J]. Proceedings of the National Academy of Sciences of the United States of America, 2007, 104(50): 19885-19890.

[33] Correa A C A, Mendoza M E, Salicrup D R P, et al. Identifying potential conservation areas in the Cuitzeo Lake Basin, Mexico by multi- temporal analysis of landscape connectivity[J]. Journal for Nature Conservation, 2014, 22(5): 424-435.

[34] Wang F, McShea W, Wang D J, et al. Evaluating landscape options for corridor restoration between giant panda reserves[J]. PLoS One, 2014, 9(8): e105086.

[35] 倪庆琳, 侯湖平, 丁忠义, 等. 基于生态安全格局识别的国土空 间生态修复分区: 以徐州市贾汪区为例 [J]. 自然资源学报, 2020, 35(1): 204-216. [Ni Q L, Hou H P, Ding Z Y, et al. Ecological remediation zoning of territory based on the ecological security pattern recognition: Taking Jiawang District of Xuzhou City as an example[J]. Journal of Natural Resources, 2020, 35(1): 204-216.]

[36] 王回茴, 李汉廷, 谢苗苗, 等. 资源型城市工矿用地系统修复的 生态安全格局构建 [J]. 自然资源学报, 2020, 35(1): 162-173. [Wang H H, Li H T, Xie M M, et al. Construction of ecological security pattern for systematic restoration of industrial and mining land in resource-based cities[J]. Journal of Natural Resources, 2020, 35(1): 162-173.]

[37] 王玉坌, 刘晓煌, 李通国, 等. 黄河流域甘肃段自然资源要素综 合调查与动态观测、监测系统建设研究[J]. 甘肃地质, 2019, 28 (Z2): 1-10. [Wang Y X, Liu X H, Li T G, et al. Investigation of natural resource elements and construction of dynamic observing and monitoring system in Gansu section of the Yellow River Basin[J]. Gansu Geology, 2019, 28(Z2): 1-10.]

[38] 黄景金, 唐长增, 李毅, 等. 广西自然资源调查监测体系构建 $[\mathrm{J}]$. 国土资源遥感, 2020, 32(2): 154-161. [Huang J J, Tang C Z, Li $\mathrm{Y}$, et al. System construction for survey and monitoring of natural resources in Guangxi[J]. Remote Sensing for Land \& Resources,
2020, 32(2): 154-161.]

[39] 张华兵, 甄艳, 吴菲儿, 等. 滨海湿地生境质量演变与互花米草 扩张的关系: 以江苏盐城国家级珍禽自然保护区为例. 资源科 学[J], 2020, 42(5): 1004-1014. [ Zhang H B, Zhen Y, Wu F E, et al. Relationship between habitat quality change and the expansion of Spartina alterniflora in the coastal area: Taking Yancheng National Nature Reserve in Jiangsu Province as an example. Resources Science[J], 2020, 42(5): 1004-1014.]

[40] 张学儒, 周杰, 李梦梅. 基于土地利用格局重建的区域生境质量 时空变化分析 [J]. 地理学报, 2020, 75(1): 160-178. [Zhang X R, Zhou J, Li M M. Analysis on spatial and temporal changes of regional habitat quality based on the spatial pattern reconstruction of land use[J]. Acta Geographica Sinica, 2020, 75(1): 160-178.]

[41] 黄晓东. 基于 InVEST 模型的江西省自然保护区空缺性分析 [D]. 南昌: 江西师范大学, 2019. [Huang X D. Vacancy Analysis of Jiangxi Nature Reserve Based on InVEST Model[D]. Nanchang: Jiangxi Normal University, 2019.]

[42] 徐羽. 江西省土地利用生态安全格局[D]. 南昌: 江西师范大学, 2017. [Xu Y. Research on Land Use Ecological Security Pattern in Jiangxi Province[D]. Nanchang: Jiangxi Normal University, 2017.]

[43] 陆禹, 余济云, 陈彩虹, 等. 基于粒度反推法的景观生态安全格 局优化: 以海口市秀英区为例 [J]. 生态学报, 2015, 35(19): 6384-6393. [Lu Y, She J Y, Chen C H, et al. Landscape ecological security pattern optimization based on the granularity inverse method: A case study in Xiuying District, Haikou[J]. Acta Ecologica Sinica. 2015, 35(19): 6384-6393.]

[44] 蒙吉军, 王晓东, 周朕. 干旱区景观格局综合优化: 黑河中游案 例[J]. 北京大学学报(自然科学版), 2017, 53(3): 451-461. [Meng J J, Wang X D, Zhou Z. Integrated landscape pattern optimization in arid region: A case study of middle reaches of Heihe River[J]. Acta Scientiarum Naturalium Universitatis Pekinensis, 2017, 53(3): 451-461.]

[45] 李青固, 张正栋, 万露文, 等. 基于景观生态风险评价的宁江流 域景观格局优化[J]. 地理学报, 2019, 74(7): 1420-1437. [Li Q P, Zhang Z D, Wan L W. Landscape pattern optimization in Ningjiang River Basin based on landscape ecological risk assessment[J]. Acta Geographica Sinica, 2019, 74(7): 1420-1437.]

[46] 黄雪飞, 吴次芳, 游和远, 等. 基于 MCR 模型的水网平原区乡村 景观生态廊道构建[J]. 农业工程学报, 2019, 35(10): 243-251. [Huang X F, Wu C F, You H Y, et al. Construction of ecological corridor of rural landscape in plain area of water network based on MCR model[J]. Transactions of the Chinese Society of Agricultural Engineering, 2019, 35(10): 243-251.]

[47] Fan F F, Liu Y X, Chen J X, et al. Scenario-based ecological security patterns to indicate landscape sustainability: A case study on the Qinghai- Tibet Plateau[J]. Landscape Ecology, 2020, DOI: 10.1007/s10980-020-01044-2.

[48] Peng J, Yang Y, Liu Y X, et al. Linking ecosystem services and circuit theory to identify ecological security patterns[J]. Science of 
the Total Environment, 2018, 644: 781-790.

[49] Liu Z H, Huang Q D, Tang G P. Identification of urban flight corridors for migratory birds in the coastal regions of Shenzhen City based on three-dimensional landscapes[J]. Landscape Ecology,
2020, DOI: $10.1007 / \mathrm{s} 10980-020-01032-6$.

[50] Galpern P, Manseau M, Fall A. Patch-based graphs of landscape connectivity: A guide to construction, analysis and application for conservation[J]. Biological Conservation, 2011, 144(1): 44-55.

\title{
Improving ecological security pattern based on the integrated observation of multiple source data: A case study of Wannian County, Jiangxi Province
}

\author{
GAO Yang ${ }^{1,2}$, LIU Yuexin ${ }^{1,2}$, Qian Jianli³, GUO You ${ }^{4}, \mathrm{HU}$ Yingshan ${ }^{4}$ \\ (1. College of Land Science and Technology, China Agricultural University, Beijing 100193, China; 2. Key Laboratory of \\ Agricultural Land Quality and Monitoring, Ministry of Natural Resources, Beijing 100193, China; 3. Xi' an Mineral Resources \\ Research Center of China Geological Survey, Xi' an 710100, China; 4. Natural Resources Comprehensive Survey Command \\ Center, China Geology Survey, Beijng 100055, China)
}

\begin{abstract}
In recent years, the lack of ecological efficiency has restricted the sustainable development of the economy and society to a certain extent. Therefore, determining the current status of natural resources and optimizing the ecological security pattern based on this is of great significance for the comprehensive development and overall spatial configuration of natural and socioeconomic factors. Taking Wannian County, Jiangxi Province as an example, this study observed the status of regional resources through land use type, digital elevation model, road, and nature reserve data. The study determined ecological sources based on the InVEST model, granularity inversion method, and current regional conditions. Land use types and terrain and road factors were used to construct a comprehensive resistance surface. The circuit theory was then applied to determine ecological corridors and identify key points for ecological restoration. The results show that: (1) The total area of the 16 ecological sources are $95.93 \mathrm{~km}^{2}$, of which forest is the main land-use type, which is crucial for the stability of the regional ecological network. The length of ecological corridors is $217.89 \mathrm{~km}$, of which 33 key corridors throughout the region need to be given priority for protection. These corridors can be used as a key area for comprehensive observation and monitoring of natural resources. (2) We identified 11 "pinch points" that are mainly ecological land distributed around high resistance areas, and 74 "barrier points" that appear in areas of intensive activities. There is much room for regional habitat connectivity improvement. (3) Based on the circuit theory, we integrated the natural resources of mountains, waters, forests, croplands, and grasslands through the point- line- surface construction process and proposed resource optimization strategies for different regions according to the ecological security pattern, which has positive practical significance for improving the structural supply capacity of regional resources.
\end{abstract}

Key words: integrated observation; ecological security pattern; ecological corridor; important strategic points; optimized resource partition; index selection; circuit theory; Wannian County 